\title{
Immunological and microbiological activity of Davilla elliptica St. Hill. (Dilleniaceae) against Mycobacterium tuberculosis
}

\author{
Flávia Cristine Mascia Lopes, Marisa Campos Polesi Placeres, \\ Cleso Mendonça Jordão Junior*, Célio Takashi Higuchi*, Daniel Rinaldo**, \\ Wagner Vilegas**, Clarice Queico Fujimura Leite*, Iracilda Zeppone Carlos/+
}

Departamento de Análises Clínicas *Departamento de Ciências Biológicas **Departamento de Química Orgânica, Unesp,
R. Expedicionários do Brasil 1601, 14801-902 Araraquara, SP, Brasil

\begin{abstract}
Mycobacterium tuberculosis is responsible for over 8 million cases of tuberculosis (TB) annually. Natural products may play important roles in the chemotherapy of TB. The immunological activity of Davilla elliptica chloroform extract (DECE) was evaluated in vitro by the determination of hydrogen peroxide $\left(\mathrm{H}_{2} \mathrm{O}_{2}\right)$, nitric oxide $(N O)$, and tumor necrosis factor- $\alpha(T N F-\alpha)$ release in peritoneal macrophages cultures. DECE was also tested for its antimycobacterial activity against $\mathrm{M}$. tuberculosis using the microplate alamar blue assay. DECE $\left(50,150,250 \mu \mathrm{g} / \mathrm{ml}\right.$ ) stimulated the production of $\mathrm{H}_{2} \mathrm{O}_{2}$ (from $1,79 \pm 0,23$ to $7,27 \pm 2,54 ; 15,02 \pm 2,86 ; 20,5 \pm 2,1$ nmols) (means $\pm S D$ ), $N O$ (from 2,64 $\pm 1,02$ to 25,59 $\pm 2,29 ; 26,68 \pm 2,41 ; 29,45 \pm 5,87$ rmols) (means $\pm S D$ ) and TNF- $\alpha$ (from 2,44 $\pm 1,46$ to 30,37 $\pm 8,13 ; 38,68 \pm 1,59 ; 41,6 \pm 0,90$ units $/ \mathrm{ml}$ ) (means $\pm S D$ ) in a dose-dependent manner and also showed a promising antimycobacterial activity with a minimum inhibitory concentration of $62,5 \mu \mathrm{g} / \mathrm{ml}$. This plant may have therapeutic potential in the immunological and microbiological control of TB.
\end{abstract}

Key words: Davilla elliptica - antimycobacterial activity - immunological activity

Mycobacterium tuberculosis is a serious threat to humankind, with over 8 million cases of tuberculosis (TB) annually (Raupach \& Kaufmann 2001). Most healthy individuals are able to control TB infection with a vigorous immune response, halting the progression of the disease, but not necessarily eradicating the microorganism (McKinney 2000). The bacterium resides within macrophages, allowing them to resist the antimicrobial effector mechanisms of the host (Raupach \& Kaufmann 2001).

The major effector molecules of antibacterial defense in macrophages include reactive oxygen intermediates (ROI) and reactive nitrogen intermediates (RNI) (Nathan \& Shiloh 2000). Hydrogen peroxide $\left(\mathrm{H}_{2} \mathrm{O}_{2}\right)$, one of the ROI generated by macrophages in a reaction catalyzed by an NADPH oxidase, was the first identified effector molecule that mediated mycobacteriocidal effects of mononuclear phagocytes (Walker \& Lowrie 1981). Nitric oxide (NO), formed by the action of the inducible form of nitric oxide synthase (iNOS), reacts with oxygen radical forming RNI. NO and related RNI have been reported to possess antimycobacterial activity (Kwon 1997).

M. tuberculosis strongly induces the release of several cytokines during infection. Tumor necrosis factor$\alpha(\mathrm{TNF}-\alpha)$ is a cytokine that plays multiple roles in immune and pathologic responses in tuberculosis, also re-

Financial support: Fapesp-Biota program (02/05503-6), CNPq ${ }^{+}$Corresponding author: carlosiz@ fcfar.unesp.br

Received 12 February 2007

Accepted 16 July 2007 quired for acute infection control (Flynn et al. 1995). It plays a major role in the recruitment of inflammatory cells to the site of infection and in the formation and maintenance of granulomas (Gaemperli et al. 2006).

Davilla elliptica St. Hill. (Dilleniaceae) is a plant popular known as cipó-caboclo. Although there are not many studies focused on this plant, it is commonly used as tonic, astringent, and laxative in the Brazilian folk medicine (Rodrigues \& Carvalho 2001). In this study, the immunological activity of D. elliptica chloroform extract (DECE) was evaluated in vitro by the determination of $\mathrm{H}_{2} \mathrm{O}_{2}$, NO, and TNF- $\alpha$ release in peritoneal macrophages cultures. DECE was also tested for its antimycobacterial activity against $M$. tuberculosis using the microplate alamar blue assay (MABA).

Plant material and samples - D. elliptica leaves were collected at Porto Nacional, Tocantins, Brazil (no. 4583 Tocantins University Herbarium). The leaves were dried at $40^{\circ} \mathrm{C}$ and then macerated with chloroform. After solvent evaporation, the extract was obtained. The extract was first solubilized in dimethyl sulfoxide (DMSO) and then diluted in an appropriated culture medium, RPMI-1640 for the immunological assays $(50,150,250 \mu \mathrm{g} / \mathrm{ml})$ and Middlebrook 7H9 for the determination of antimycobacterial activity $(62,5-4000 \mu \mathrm{g} / \mathrm{ml})$.

Animals - Experiments involving Swiss mice (6-8 weeks old, 18 to $25 \mathrm{~g}$ ) were performed in accordance with the regulations of Research Ethics Committee (\# 01/2005), Faculty of Pharmaceutical Sciences, Unesp, São Paulo, Brazil.

Peritoneal macrophages - Thioglycollate-elicited peritoneal exsudate cells (PEC) were harvested from Swiss mice using $5 \mathrm{ml}$ of sterile PBS, pH 7.4. The cells 
were washed twice by centrifugation at $200 \mathrm{~g}$ for $5 \mathrm{~min}$ at $4{ }^{\circ} \mathrm{C}$ and ressuspended in an appropriate medium for each test. MTT assay was performed to assure the viability of the cells in the presence of DECE (Mosmann 1983) (data not shown).

Measurement of $\mathrm{H}_{2} \mathrm{O}_{2}$ production $-\mathrm{H}_{2} \mathrm{O}_{2}$ release was measured using the horseradish peroxidase-dependent phenol red oxidation microassay according to Pick and Mizel (1981). Cells incubated with phorbol myristate acetate (PMA) $0.2 \mathrm{mM}$ only were used as a positive control.

Measurement of NO production - NO production induced by DECE was determined by assaying culture supernatants for nitrite using Griess reagent according to Green et al. (1982). Cells incubated with $1 \mu \mathrm{g} / \mathrm{ml}$ of lipopolysacharide (LPS) from Escherichia coli O111:B4 were used as a positive control.

Measurement of TNF- $\alpha$ production - The determination of TNF- $\alpha$ in the supernatants was based in its property to destroy L929 tumoral cell line (Carlos et al. 1994). LPS ( $1 \mu \mathrm{g} / \mathrm{ml})$ was used as a positive control.

Determination of antimycobacterial activity (MABA technique) - The minimum inhibitory concentration (MIC) of DECE was determined against M. tuberculosis H37Rv (American Type Culture Collection 27294) $\left(10^{7} / \mathrm{ml}\right)$ in Middlebrook $7 \mathrm{H} 9$ medium using the MABA (Collins \& Franzblau 1997). The classic antimycobacterial drug isoniazide (INH) (Sigma) $(0,015-1 \mu \mathrm{g} / \mathrm{ml})$ was used as a reference drug.

Statistical analysis - The results are expressed as means \pm SD of five experiments. One-way ANOVA with Dunnett's post test was performed using GraphPad InStat (San Diego, California, US) with the level of significance set at $\mathrm{p}<0.05$.

In recent years, emerging multiple drug resistance has become a major threat and thus calls for an urgent search for new and effective treatments for this deadly disease. Naturally occurring compounds as extracts from plants have indicated that inhibitory activity against $M$. tuberculosis is widespread in nature (Okunade et al. 2004).

In the present study, it was demonstrated that addition of different concentrations of DECE extract (50, $150,250 \mu \mathrm{g} / \mathrm{ml})$, to cultured macrophages, triggered the production of $\mathrm{H}_{2} \mathrm{O}_{2}$ (from $1,79 \pm 0,23$ to $7,27 \pm 2,54$; $15,02 \pm 2,86 ; 20,5 \pm 2,1 \mathrm{nmols}$ ) (means $\pm \mathrm{SD}$ ) (Fig. 1), NO (from 2,64 $\pm 1,02$ to $25,59 \pm 2,29 ; 26,68 \pm 2,41$; $29,45,9 \mu$ mols) (means \pm SD) (Fig. 2) and TNF- $\alpha$ (from $2,44 \pm 1,46$ to $30,37 \pm 8,13 ; 38,68 \pm 1,59 ; 41,6 \pm 0,9$ units $/ \mathrm{ml}$ ) (means $\pm \mathrm{SD}$ ) (Fig. 3) in a dose-dependent manner. The discrete but significant production of the three studied mediators $\left(\mathrm{H}_{2} \mathrm{O}_{2}, \mathrm{NO}\right.$ and TNF- $\alpha$ ) by DECE stimulated macrophages is very important, since macrophages produces several effector molecules that can enhance or restore the ability of the immune system to fight against TB infection.

It is well know that $\mathrm{H}_{2} \mathrm{O}_{2}$ is an effective microbial disinfectant, destroying pathogens by an oxidation process that results in protein denaturation (Hughes et al. 2003). Studies have shown that M. tuberculosis infection induces the accumulation of macrophages in the lung and in the ascitic fluid and also $\mathrm{H}_{2} \mathrm{O}_{2}$ production in patients with pulmonary tuberculosis and tuberculous ascites (Swamy et al. 1988, Raja 2004).

Phagocytes kill intracellular organisms during an initial oxidative phase dependent on NADPH oxidase, followed by a prolonged nitrosative phase, during which bacterial growth is inhibited by iNOS (Nathan \& Shiloh 2000). There are several potential mechanisms that can explain how NO may affect microbial life-cycle. NO and

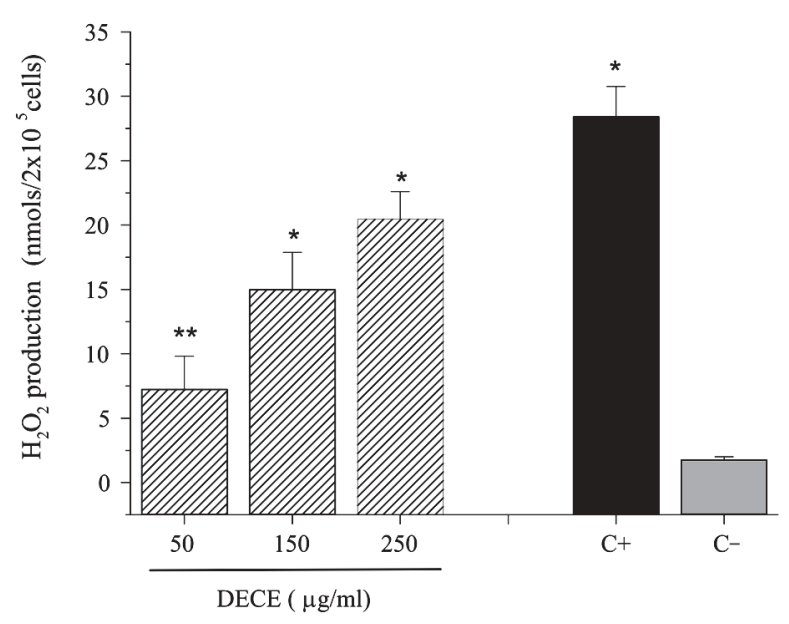

Fig. 1: induction of hydrogen peroxide production by Davilla elliptica chloroform extract from peritoneal macrophages. Cells incubated with phorbol myristate acetate $(0.2 \mathrm{mM})$ were used as a positive control $(\mathrm{C}+)$ and cells in potassium phosphate buffer as a negative control (C-). Data are reported as the mean \pm SD for at least four independent experiments carried out in triplicate. One-way ANOVA with Dunnett's post test was performed; * $p<0.01$ vs $\mathrm{C}-$; ** $p<0.05$ vs $\mathrm{C}-$.

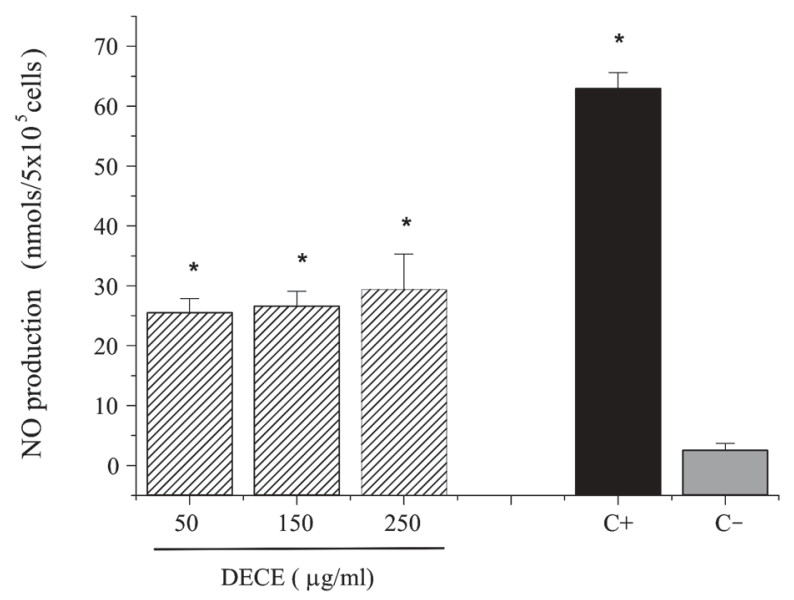

Fig. 2: induction of nitric oxide (NO) production by Davilla elliptica chloroform extract from peritoneal macrophages. Cells incubated with lipopolysacharide $(1 \mu \mathrm{g} / \mathrm{ml})$ were used as a positive control $(\mathrm{C}+)$ and cells in culture medium (RPMI-1640) as a negative control (C-). Data are reported as the mean $\pm \mathrm{SD}$ for at least four independent experiments carried out in triplicate. One-way ANOVA with Dunnett's post test was performed; * $p<0.01$ vs $\mathrm{C}-$. 


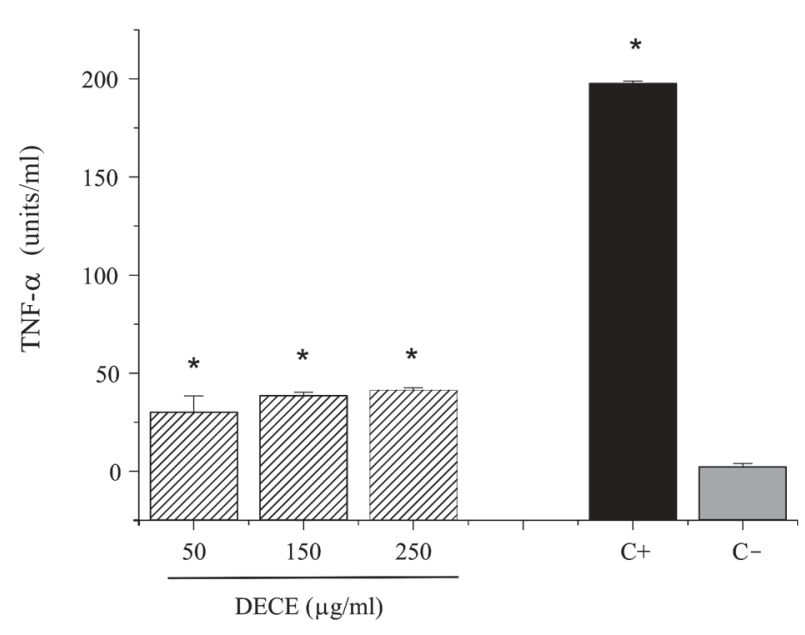

Fig. 3: induction of tumor necrosis factor- $\alpha$ production by Davilla elliptica chloroform extract from peritoneal macrophages. Cells incubated with lipopolysacharide $(1 \mu \mathrm{g} / \mathrm{ml})$ were used as a positive control $(\mathrm{C}+)$ and cell in culture medium (RPMI-1640) as a negative control (C-). Data are reported as the mean $\pm \mathrm{SD}$ for at least four independent experiments carried out in triplicate. One-way ANOVA with Dunnett's post test was performed; $* p<0.01$ vs $\mathrm{C}-$.

other RNI can modify bacterial DNA, protein and lipids at both the microbial surface and intracellularly. They can alter cytokine production and induce or prevent apoptosis of host cells by controlling caspase activity (Raupach \& Kaufmann 2001). NO can also interact with accessory protein targets, resulting in enzymatic inactivation or other protein malfunctions (Gow et al. 1999). Besides that, NO reacts with superoxide to form a strong oxidant, peroxynitrite $\left(\mathrm{ONOO}^{-}\right)$. $\mathrm{ONOO}^{-}$mediates nitrosylation of tyrosine residues, and therefore has the potential to disrupt tyrosine phosphorylation-dependent signaling pathways (Linares et al. 2001).

Studies in mouse infection models have clearly revealed that TNF- $\alpha$ is a crucial component of both the antibacterially protective and the inflammatory immune response to $M$. tuberculosis. It is necessary for optimal co-ordination of both the differentiation of specific T cells to secrete the appropriate $\mathrm{T}$ helper 1 cytokines and the development of granulomas in which activated macrophages restrict mycobacterial growth (Ehlers 2003). TNF- $\alpha$ is required for control of latent TB and it is also a key element for activating macrophages to produce iNOS and thus in maintaining the pathway for generating NO and preventing reactivation of the disease (Adams et al. 1995).

In our research, DECE exhibited a antimycobacterial activity $(\mathrm{MIC}=62,5 \mu \mathrm{g} / \mathrm{ml})$, indicating that the extract could be an important source of bactericidal compounds against $M$. tuberculosis. Although still being less potent than the reference drug INH $(\mathrm{MIC}=0,03 \mu \mathrm{g} / \mathrm{ml})$, we have to consider that $D$. elliptica extract was tested and not pure compounds as the study conducted by Akihisa et al. (2005). In this research, 15 pure compounds with MIC values of 4-64 $\mu \mathrm{g} / \mathrm{ml}$ were isolated from the flower extract of Chrysanthemum morifolium and showed high activity against $M$. tuberculosis, being considered valuable from the viewpoint of anti-TB.

Recent advances in understanding the host-pathogen interaction created new approaches for the development of new antimycobacterial agents. In the present work, it was demonstrated that DECE exhibited promising results suggesting that this plant may have therapeutic potential in the immunological and microbiological control of TB.

\section{REFERENCES}

Adams LB, Mason CM, Kolls JK, Scollard D, Krahenbuhl JL, Nelson S 1995. Exacerbation of acute and chronic murine tuberculosis by administration of a tumor necrosis factor receptor-expressing adenovirus. J Infect Dis 171: 400-405.

Akihisa T, Franzblau SG, Ukiya M, Okuda H, Zhang F, Yasukawa K, Suzuki T, Kimura Y 2005. Antitubercular activity of triterpenoids from Asteraceae flowers. Biol Pharm Bull 28: 158-160.

Carlos IZ, Sgarbi DBG, Angluster J, Alviano CS, Silva CL 1994. Disturbances in the production of interleukin-1-necrosis and tumor necrosis factor in disseminated murine sporotrichosis. Mycopathologia 127: 189-194.

Collins LS, Franzblau SG 1997. Microplate alamar blue assay versus BACTEC 460 system for high-throughput screening of compounds against Mycobacterium tuberculosis and Mycobacterium avium. Agents Chemother 41: 1004-1009.

Ehlers S 2003. Role of tumour necrosis factor (TNF) in host defence against tuberculosis: implications for immunotherapies targeting TNF. Ann Rheum Dis 62(Suppl. 2): ii37-ii42.

Flynn JL, Goldstein MM, Chan J, Triebold KJ, Pfeffer K, Lowenstein CJ, Schreiber R, Mak TW, Bloom BR 1995.Tumor necrosis factor- $\alpha$ is required in the protective immune response against M. tuberculosis in mice. Immunity 2: 561-572.

Gaemperli A, Hauser T, Speck RF 2006. Risk of infection during treatment with tumor necrosis factor-alpha inhibitors. Z Rheumatol 65: 24-31.

Gow, AJ, Foust R, Malcolm S, Gole M, Ischiropoulos H 1999. Biochemical regulation of nitric oxide cytotoxicity. In FC Fang, Nitric Oxide and Infection, Kluwer Academic/ Plenum Publishers, New York, p. 175-187.

Green LC, Wagner DA, Glogowski J, Skipper PL, Wishnok JS, Tannenbaum SR 1982. Analysis of nitrate, nitrite, and $\left[{ }^{15} \mathrm{~N}\right]$ nitrate in biological fluids. Analytic Biochem 126: 131-138.

Hughes R, Andrew PW, Kilvington S 2003. Enhanced killing of Acanthamoeba cysts with a plant peroxidase-hydrogen peroxide-halide antimicrobial system. Appl Environ Microbiol 69: 2563-2567.

Kwon OJ 1997. The role of nitric oxide in the immune response of tuberculosis. Korean Med Sci 12: 481-487.

Linares E, Giorgio S, Mortara RA, Santos CXC, Yamada AT, Augusto O 2001. Role of peroxynitrite in macrophage microbicidal mechanisms in vivo revealed by protein nitration and hydroxylation. Free Rad Biol Med 30: 1234-1242.

McKinney JD 2000. In vivo veritas: the search for TB drug targets goes live. Nat Med 6: 1330-1333.

Mosmann T 1983. Rapid colorimetric assay for cellular growth and survival: application to proliferation and cytotoxicity assays. J Immunol Methods 65: 55-63. 
Nathan C, Shiloh MU 2000. Reactive oxygen and nitrogen intermediates in the relationship between mammalian hosts and microbial pathogens. Proc Natl Acad Sci USA 97: 8841-8848.

Okunade AL, Elvin-Lewis MP, Lewis WH 2004. Natural antimycobacterial metabolites: current status. Phytochemistry 65: 1017-1032.

Pick E, Mizel DJ 1981. Superoxide anion and hydrogen peroxide production by chemically elicited peritoneal macrophages induction by multiple nonphagocytic stimuli. J Immunol Methods 46: 211-226.

Raja A 2004. Immunology of tuberculosis. Indian J Med Res 120: 213-232.
Raupach B, Kaufmann SHE 2001. Immune responses to intracellular bacteria. Curr Opin Immunol 13: 417-428.

Rodrigues VEG, Carvalho DA 2001. Levantamento etnobotânico de plantas medicinais no domínio do cerrado na região do Alto Rio Grande, MG. Ciênc agrotec 25: 102-123.

Swamy R, Acharyalu GS, Balasubramaniam R, Narayanan PR, Prabhakar R 1988. Immunological investigations in tuberculous ascites. Indian J Tuberc 35: 3-7.

Walker L, Lowrie DB 1981. Killing of Mycobacterium microti by immunologically activated macrophages. Nature 293: 69-70. 